American Journal of Pharmaceutical Education 2016; 80 (6) Article 93.

\title{
VIEWPOINT
}

\section{Are Great Teachers Great Storytellers?}

\author{
Frank Romanelli, PharmD, MPH ${ }^{\mathrm{a}, \mathrm{b}}$ \\ ${ }^{a}$ University of Kentucky College of Pharmacy, Lexington, Kentucky \\ ${ }^{\mathrm{b}}$ Associate Editor, American Journal of Pharmaceutical Education, Alexandria, Virginia
}

Educators and administrators alike can spend a lifetime trying to define great teaching and great teachers. Researchers have ventured into scholarship in this area to best define what separates "good ones" from "not so good ones." 1,2 Is it that they care more? Are good teachers more entertaining or more prepared? Is it their sense of humor or the fact that they challenge on a different level?

Potts and Davis described outstanding teachers as those who "make things stick." 3 The question then becomes what makes the things we teach sticky or stickier? In preparation for instructing a new module called "Transitions in Pharmacy" at our college, I was asked to read a book that was a component of a summer reading assignment for incoming first professional year doctor of pharmacy (PharmD) students. The novel Brain Storms was intended to serve as a "launch pad" for a boot camp series envisioned to prepare students for a new PharmD curriculum. ${ }^{4}$

The nonfiction work is narrated by a journalist who tells the story of Parkinson's disease, from James Parkinson's first reported observations of a movement disorder titled "An Essay on the Shaking Palsy," through modern day start-up companies and their explorations of misfolded proteins as a root cause for the disease. In the course of the book, the author reveals that he was recently diagnosed with Parkinson's. While neurology is not my field of expertise, I found myself drawn into the book and the story, and I learned a lot.

Have we as teachers forgotten the importance of storytelling? Some speculate that growing demands to teach more to more students alongside the overreliance on PowerPoint presentations and other technologies have led many educators to stray from telling the larger story. Stories are a connected means of presenting and transmitting information. Moreover, information that is presented in a logical and systematic fashion is often easier for students to understand, process, retrieve, and synthesize. Perhaps the greatest strength of storytelling is the naturalness of this mode of information transmission. For most of us, our education started informally through fairy tales, fables, and even family stories.
The effective use of storytelling as a component of teaching may be too often overlooked. Telling the story of a disease, disease state, or any lesson on a micro or macro level may be invaluable to students. The story of a disease helps learners understand circumstances surrounding recognition of an altered health state and the chronological events that shape the pharmacotherapy used to treat or cure. By providing a narrative account, a storyline forces students to better understand the circumstances that lead to drug discoveries, obstacles to treatment, and advantages and disadvantages of specific therapeutic options. A paramount lesson from the narrative is comprehending what leads researchers or clinicians to ask certain questions or make certain hypotheses concerning a disease.

In many ways, the narrative of the story allows students to hear others "thinking out loud." For example, the story of AIDS would begin with an understanding of the peculiarities of initial symptoms caused by the disease followed by a discussion of what led researchers to suspect a virus as the root cause. Storytelling should not be considered solely a teaching tool used in the clinical sciences. Instructing the pharmacology of antibiotics might precede with the recognition that bacteria replicate extracellularly, followed by the discovery of penicillin and the subsequent antibiotic classes, including the antistaphylococcal penicillin and the "generational" introduction of the cephalosporin interspersed with the history of bacterial resistance. In both of these instances, there is a true story to be told, one with a beginning or prologue, a middle, and an end or epilogue.

As teachers, we all get a "buzz" from seeing students' light bulbs go off. Storytelling may be one of the most effective ways to get the bulbs to light up. Remembering a list of facts or pieces of information becomes less burdensome when they are interconnected. The connectivity of facts moves students away from simple memorization to true understanding, thus easing recall. Comprehending a story behind facts or disease states or pharmacotherapy also may impart a greater sense of ownership and self-confidence in one's abilities to manipulate information and potentially generate new 


\section{American Journal of Pharmaceutical Education 2016; 80 (6) Article 93.}

hypotheses, contextual links, or areas of creativity or discovery. We should be reminded that the wildly popular TED Talk series uses a platform where learning is centered on some short narrative.

The nature of pharmacy and health care is a story. Even the simplest fairy tales raise questions or pose potential conflicts. The characters in the story encounter these conflicts in different ways. In some instances, crises are resolved or believed to be resolved (eg, small pox). In other instances, crises may be altered but leave the reader waiting for the next chapter or series (eg, HIV). The common thread is the creation of interest, understanding, and engagement. Consider that learners may be better adapted to understand logic not simply as logic but through the prism of a story. The story may be the most powerful tool in the teacher's armamentarium. So, the next time you are in the classroom, consider taking the time to tell a story.

\section{REFERENCES}

1. Schor EL, Grayson M. Outstanding clinical teachers: methods, characteristics and behaviors. Res Med Educ. 1984;23:271-276.

2. O'Sullivan TA, Lau C, Patel M, et al. Student-valued measureable teaching behaviors of award-winning pharmacy preceptors. Am J Pharm Educ. 2015;79(10):Article 151.

3. Potts DA, Davis KF. Making education stick! J Emerg Nurs. 2009;35(4):375-378.

4. Palfreman J. Brain Storms: The Race to Unlock the Mysteries of Parkinson's Disease. New York, NY: Scientific American / Farrar, Straus and Giroux; 2015. 